\title{
Habitat preference and reproductive traits in the Antarctic midge Parochlus steinenii (Diptera: Chironomidae)
}

\author{
STEFFEN HAHN ${ }^{1 *}$ and KLAUS REINHARDT ${ }^{2}$ \\ ${ }^{1}$ Institute of Ecology, Bird \& Polar Ecology Group, Friedrich-Schiller University Jena, Dornburger Strasse 159, D-07743 Jena, Germany \\ ${ }^{2}$ Department of Animal \& Plant Sciences, University of Sheffield, Sheffield S10 2TN, UK \\ * current address: Department of Plant-Animal Interactions, Centre for Limnology, Netherlands Institute of Ecology (NIOO-KNAW), \\ PO Box 1299, 3600 BG Maarssen, the Netherlands \\ S.Hahn@nioo.knaw.nl
}

\begin{abstract}
We provide the first comprehensive account of habitat preference, mating, oviposition and developmental stages of Parochlus steinenii. There are eight records from the South Shetland Islands. On King George Island, none out of 40 temporary ponds and $9 \%$ out of 44 lakes with variable water levels were inhabited by P. steinenii. By contrast, $94 \%$ of 52 lakes with stable water levels were occupied, for $92 \%$ of which breeding was confirmed. Lakes were occupied independently of their height above sea level ranging from 5 to $115 \mathrm{~m}$. The midges aggregated at two different microhabitats at the shoreline of lakes. Terrestrial swarms of more than 5000 individuals at open wind sheltered rocks were strongly dominated by males. Their mean density was 40, their maximum 150 ind. $\mathrm{cm}^{-2}$. Aggregations under stones at the water edge showed a female-biased or equal sex ratio; their densities seasonally increased from 0.17 to $2.02 \mathrm{ind} \mathrm{cm}^{-2}$. Female midges produced one to four egg batches totalling on average 247 eggs/female. Four larval stages can be clearly discriminated by head length. Our data on the habitat preferences and the high reproductive output predict that $P$. steinenii will rapidly colonize habitats that become available in the course of the regional warming of the Antarctic Peninsula region.
\end{abstract}

Received 3 June 2005, accepted 24 October 2005

Key words: climate change, freshwater, lake, Maritime Antarctic, population, sex ratio, swarm

\section{Introduction}

The South Shetland Islands and the western part of the Antarctic Peninsula are one of the best investigated Antarctic regions and have the highest terrestrial biodiversity in the Antarctic (e.g. Convey 2001). This allows critical assessments of recent biological changes associated with the rapid regional warming (Vaughan et al. 2003). Evidence for changes in the terrestrial ecosystem comes from communities of microarthropods (reviewed in Convey 2001, 2003), range size extension of plants (Fowbert \& Smith 1994, Gerighausen et al. 2003) or successful establishment of alien species (Smith 1996, Frenot et al. 2005). While the response to future climate change will differ between terrestrial Antarctic species, sensible predictions require an in-depth knowledge of the ecological factors that favour or restrict reproduction and development.

Chironomidae are keystone species in freshwater ecosystems because of their high productivity (Tokeshi 1997). In the Antarctic, one of the most abundant but among the least known terrestrial animals is a chironomid midge, the winged species Parochlus steinenii Gerke, 1889. Outside Tierra del Fuego (South America) it inhabits freshwater and probably brackish water from South Georgia to the South Shetland Islands (Gerke 1889, Torres 1956, Brundin 1966, Vogel \& Nicolai 1983). It is not present on the South Orkney Islands or the northern Antarctic Peninsula (Convey \& Block 1996). Although its role in freshwater habitats of the Antarctic is not known, high recorded larval densities of $P$. steinenii (330-580 larvae $\mathrm{m}^{-2}$, Richard et al. 1994) suggests that a significant role is likely. Data on the distribution, ecology and reproduction are almost entirely based on sporadic observations (Convey \& Block 1996). Adults of both sexes have been found during the Antarctic summer at the edge of lakes, ponds and streams (Edwards \& Usher 1985, Rauschert 1985), where copulation occurs (Richard et al. 1994). Larvae overwinter (Rauschert 1985) but show, like adults, an unexpectedly low degree of cold hardiness (Shimada et al. 1991). The contemporary rapid increase in average air temperature in this part of Antarctica may facilitate successful colonization by $P$. steinenii but, alternatively, increased desiccation or variability in water level may lead to the opposite. In this paper we address the field distribution, habitat preferences, reproduction and development of this Antarctic midge on King George Island (South Shetland Islands) in detail. These, and additional laboratory observations on key reproductive and developmental parameters, will improve our knowledge on this species and allow us to predict initially how $P$. steinenii is likely to benefit from the altered climatic conditions currently seen in the South Shetland Islands. 


\section{Materials and methods}

Study area

The study was carried out at four ice-free areas on King George Island, Potter Peninsula $\left(62^{\circ} 14 ' \mathrm{~S}, 58^{\circ} 39^{\prime} \mathrm{W}\right)$, Barton Peninsula $\left(62^{\circ} 13^{\prime} \mathrm{S}, 58^{\circ} 47^{\prime} \mathrm{W}\right)$, Fildes Peninsula $\left(62^{\circ} 12^{\prime} \mathrm{S}\right.$, $\left.58^{\circ} 54^{\prime} \mathrm{W}\right)$ and Ardley Island $\left(62^{\circ} 12^{\prime} \mathrm{S}, 58^{\circ} 56^{\prime} \mathrm{W}\right)$. The latter two sites are separated by an isthmus of only $200 \mathrm{~m}$ width. The climate is typical of the maritime Antarctic: average summer air temperatures exceed zero during December-March though remaining less than $2^{\circ} \mathrm{C}$, annual precipitation (c. $460 \mathrm{~mm}$ ) and humidity (up to $95 \%$ ) are high. The geomorphology of ice-free areas is determined by periglacial landforms with numerous temporary shallow meltwater ponds and permanent lakes which are icecovered 9-10 months each year (Barsch et al. 1985). The highest elevations reach $167 \mathrm{~m}$ (Horatio Stump, Fildes Peninsula) and $266 \mathrm{~m}$ (Noel Hill, Barton Peninsula).

\section{Habitat preferences}

Large-scale distribution records of this species were collated from the literature, including information on the habitat type and precise locations. At a smaller scale, distribution was investigated on Fildes Peninsula, Ardley Island and Barton Peninsula from 13 January-3 February 2005. The banks of almost all permanent freshwater lakes and a similar number of temporal pools were searched for adult midges and egg clutches or larvae (Fildes Peninsula including Ardley Island: 105 sites, Barton Peninsula: 31 sites). Their presence/absence were recorded by investigating the undersides of all stones situated in an area of approximately $1 \mathrm{~m} \times 0.5 \mathrm{~m}$. At small ponds at least one site per water body was surveyed. At larger ponds or lakes these surveys were carried out at every $30 \mathrm{~m}$ of shoreline. Three freshwater habitats were distinguished. Temporary water bodies were characterized by submerged lichens or mosses and red-brownish cyanobacterial mats (Phormidium spp.) at the water edge. These are an indicator for shallow water with variable levels (P. Convey, personal communication 2005). Permanent water bodies with variable water level were characterized by the presence of signs of older shore edges such as water markings on rocks, accumulated fine grained substrates and the occurrence of Phormidium mats. The final category included permanent water bodies with a stable water level.

We classified shoreline substrata as fine grained materials (mud, sand), or stones of small $(<3 \mathrm{~cm})$, medium $(4-10 \mathrm{~cm})$ and large size ( $>10 \mathrm{~cm}$ in diameter), and recorded the presence of snow/ice at the shoreline. Habitat extent was measured as the total shoreline length. The elevation above sea level and the distance to nearest occupied site were also noted from existing maps and with GPS, respectively.

We analysed habitat occupation (presence/absence) by midges using binary logistic regression. Insignificant variables were excluded stepwise from the full model based on likelihood ratio iterations. For the General Linear Model analyses, habitat size and distance data were logtransformed for normal distribution.

\section{Aggregation and reproduction}

Aggregations of midges occurred in two different microhabitats: the underside of stones directly at the shoreline and on the lee side of rocks at the shoreline. The temporal nature of such aggregations was investigated using five cross section searches of the underside of stones at a permanent lake. These surveys were carried out at regular intervals between 20 January and 4 March 1996 on Potter Peninsula. All individuals found on or under 8-10 stones were collected. The surface area of each of these stones was measured.

Lee sides of rocks $(n=8)$ were sampled in January and February 2005 at Lake Kitesh (Fildes Peninsula) and Lake Ripamonti (Ardley Island). For these samples all individuals within a $2 \times 2 \mathrm{~cm}$ grid were captured from large aggregations using an aspirator. The total area of the rock covered by the aggregation was measured and the size of aggregation was estimated. Individuals were stored in ethanol and later counted and sexed to give an average density of individuals and the sex ratio for each sample and microhabitat.

The relative occurrence of mating pairs in each habitat type was investigated on 24 January and 1 February 1994 at a permanent lake on Potter Peninsula. On both days, thirty stones were carefully turned and the number of males,

Table I. Present distribution of Parochlus steinenii on the South Shetland Islands.

\begin{tabular}{llll}
\hline Site & & Habitat & Source \\
\hline Penguin Island & $62^{\circ} 06^{\prime} \mathrm{S} 57^{\circ} 56^{\prime} \mathrm{W}$ & Slightly brackish water & Cited in Wirth \& Gressit 1967 \\
Pt Thomas, Admiralty Bay / KGI & $62^{\circ} 10^{\prime} \mathrm{S}, 58^{\circ} 28^{\prime} \mathrm{W}$ & Lakes & T. Zadrozny, personal communication 2005 \\
Fildes Peninsula / KGI & $62^{\circ} 12^{\prime} \mathrm{S} 58^{\circ} 54^{\prime} \mathrm{W}$ & Lakes, streams & Rauschert 1985, Shimada et al. 1991, this study \\
Ardley Island & $62^{\circ} 12^{\prime} \mathrm{S} 58^{\circ} 56^{\prime} \mathrm{W}$ & Lakes & Edwards \& Usher 1985, this study \\
Barton Peninsula / KGI & $62^{\circ} 13^{\prime} \mathrm{S} 58^{\circ} 47^{\prime} \mathrm{W}$ & Lakes & this study \\
Potter Peninsula / KGI & $62^{\circ} 14^{\prime} \mathrm{S} 58^{\circ} 39^{\prime} \mathrm{W}$ & Lakes & Torres 1956, this study \\
Robert Island & $62^{\circ} 24^{\prime} \mathrm{S} 59^{\circ} 31^{\prime} \mathrm{W}$ & Flat ground in depressions & Cited in Wirth \& Gressit 1967 \\
Byers Peninsula / Livingston Island & $62^{\circ} 37^{\prime} \mathrm{S} 61^{\circ} 07^{\prime} \mathrm{W}$ & Lakes and streams & Greene et al. 1967, Edwards \& Usher 1985, Richard et al. 1994 \\
\hline
\end{tabular}

KGI $=$ King George Island 
Table II. Habitat preferences of the Antarctic midge Parochlus steinenii at Fildes Peninsula including Ardley Island and Barton Peninsula (King George Island. Habitat use is given by occupation and confirmed breeding of different habitat types. Data are percent of total sample size $(n)$ of each habitat.

\begin{tabular}{lcccccr}
\hline Habitat type & \multicolumn{3}{c}{$\begin{array}{c}\text { Fildes Peninsula } \\
\text { Occupied Breeding } \\
\end{array}$} & \multicolumn{4}{c}{$\begin{array}{c}\text { Barton Peninsula } \\
\text { Occupied Breeding } n\end{array}$} \\
\hline Temporary ponds & 0 & 0 & 32 & 0 & 0 & 8 \\
Lakes with variable water level & 9.3 & 6.2 & 32 & 8.3 & 0 & 12 \\
Lakes with constant water level & 95.1 & 87.8 & 41 & 90.8 & 72.8 & 11 \\
\hline
\end{tabular}

females and mating pairs counted. In addition, aggregation in wind sheltered sites of stones was observed until 50 mating pairs were seen. The start of seven matings was observed and timed. Seven egg batches were collected at this site.

In the 1996 season, pairs of midges collected on Potter Peninsula were kept alive in individual tubes $(50 \mathrm{ml})$ to allow copulation. After $2 \mathrm{~h}$ females were removed and kept isolated in a single petri dish (10 $\mathrm{cm}$ in diameter). This petri dish contained freshwater and one small stone as an egg laying substrate. A total of 57 females were thus investigated. The petri dish was checked twice a week. The number of clutches was recorded and the number of eggs per clutch counted using a stereoscope (magnification up to $x$ 80). Additionally, the length and width of a random sample of 21 eggs from 15 females was measured.

Petri dishes containing eggs were exposed to ambient weather conditions to guarantee natural light regimes for further larval development by leaving them with closed lid in the shade outside the laboratory. Eleven to 35 days after hatching larvae were collected and stored in ethanol. The length of the head capsule, an indicator of size, was measured at a minimum magnification $\mathrm{x} 100$ (Schmid 1993). To increase sample size two additional random samples were taken from a breeding habitat near Lake Kitesh (Fildes Peninsula) in January and February 2005.

\section{Results}

\section{Habitat preferences}

Parochlus steinenii has been recorded from eight distinct

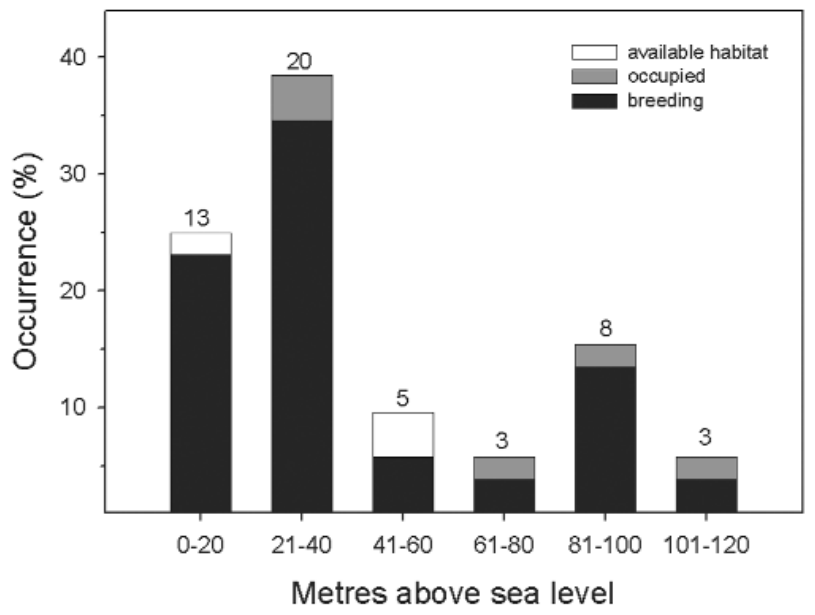

Fig. 1. Vertical occurrence of suitable lakes with stable water levels and their proportional occupation as well as use as breeding sites by Antarctic midges. Data from Fildes and Barton Peninsula were pooled and categorized in intervals of $20 \mathrm{~m}$ size. The bars give the availability of suitable habitats, grey and black symbolise the proportional occupation and use as breeding site, respectively. The numerals give the number of lakes per category.

areas of five different islands in the South Shetland Islands (Table I). Most records appear to be from permanent habitats such as lakes and streams, but the distinction between permanent and temporary water bodies is not always clear in the literature.

On the western part of King George Island midges are widely distributed at Fildes and Barton Peninsula. The proportion of occupied sites did not differ between two study sites (Fildes Peninsula including Ardley Island and Barton Peninsula, $\chi^{2}=0.07, P=0.79$; Table II), allowing data to be combined. Lakes with fluctuating water levels and temporal melting ponds were rarely ( $9.1 \%$ of 44 sites) or never occupied by adult $P$. steinenii (Table II). The species was found in $94 \%$ of all lakes with stable water level on Fildes Peninsula, Ardley Island and Barton Peninsula. Breeding was confirmed for $92 \%$ of the occupied lakes by the presence of eggs and/or larvae. The midges were recorded from suitable lakes from the coast to the high plains at both Fildes (range: 10-115 m) and Barton

Table III. Habitat characteristics (factors) explaining the occurrence and breeding of Parochlus steinenii in freshwater habitats of Fildes and Barton peninsulas, King George Island. Data are the regression coefficients (Beta) \pm SE, Wald statistics and significance level $(P)$.

\begin{tabular}{|c|c|c|c|c|c|c|}
\hline \multirow[t]{2}{*}{ Factor } & \multicolumn{3}{|c|}{ Occurrence } & \multicolumn{3}{|c|}{ Breeding } \\
\hline & Beta $\pm \mathrm{SE}$ & Wald & $P$ & Beta $\pm \mathrm{SE}$ & Wald & $P$ \\
\hline Habitat type & $6.45 \pm 1.41$ & 20.90 & 0.001 & $5.29 \pm 1.13$ & 21.98 & 0.001 \\
\hline Distance to occupied site & $-0.01 \pm 0.01$ & 6.39 & 0.011 & - & & 0.08 \\
\hline Habitat size & $0.01 \pm 0.01$ & 5.05 & 0.025 & - & & 0.14 \\
\hline Rock size & $-0.15 \pm 0.08$ & 3.90 & 0.048 & $-0.13 \pm 0.06$ & 4.23 & 0.04 \\
\hline Constant & $-12.67 \pm 2.65$ & 22.80 & 0.001 & $-11.37 \pm 2.41$ & 22.29 & 0.001 \\
\hline Height above sea level & - & & 0.23 & - & & 0.40 \\
\hline Snow/ice occurrence & - & & 0.47 & - & & 0.81 \\
\hline
\end{tabular}


Peninsula (range: 5-110 m, Fig. 1). The size of occupied habitats varied from water bodies with a $2 \mathrm{~m}$ shoreline (very small pond in the outlet of a large lake) to a $1260 \mathrm{~m}$ shoreline (median $272 \mathrm{~m}$ ). On average, unoccupied water bodies were smaller than occupied sites (median all unoccupied sites: $108 \mathrm{~m}$, median permanent $\&$ unoccupied site: $146 \mathrm{~m}$; GLM: factor habitat size * habitat type: $\mathrm{F}_{3,132}=$ 14.27, $P=0.001)$. Overall, occupied habitats were not situated further away from the next unoccupied site (372 \pm $205 \mathrm{~m})$ than from each other $(342 \pm 197 \mathrm{~m}$, GLM: factor occupation: $\mathrm{F}_{1,136}=0.05, P=0.82$, factor study area: $\mathrm{F}_{1,136}=$ $0.73, P=0.40)$.

Our habitat parameters explained $66 \%$ of the variation in the occurrence of $P$. steinenii (binary regression, Cox-Snell $r^{2}=0.66, n=132$ ). The most significant predictor was habitat type, followed by distance to the nearest occupied site, habitat size and stone size as substrate at the water edge (Table III). Neither elevation above sea level, nor the occurrence of snow/ice at the shore contributed significantly to the model (all $P>0.05$, Table III).

Breeding was predicted by the factors habitat type and stone size as substrate at the water edge (Cox-Snell $r^{2}=$ $0.58, n=132$, all others $P>0.05$, Table III).

\section{Aggregation and reproduction}

Aggregations of adult midges were regularly found on the underside of stones or on the lee side of rocks at the shore of lakes. During very calm weather conditions midges were also seen to form aggregations of several hundred individuals drifting on the water surface (lakes Kitesh and Glubokoye on Fildes Peninsula, January 2005) as previously observed (Rauschert 1985).

Mean densities on the underside of stones ranged from $0.17 \pm 0.11$ to $2.02 \pm 0.98$ ind. $\mathrm{cm}^{-2}$. In 1996 , there was a tenfold seasonal increase from January to March (linear

Table IV. Density and sex ratio of ground aggregations of Parochlus steinenii in different microhabitats on King George Island. Density is given as mean ind. $/ \mathrm{cm}^{2} \pm \mathrm{SD}$ covered by the aggregation (area). Sex ratio gives number of males/female. The abbreviation of samples are $\mathrm{PP}=$ Potter Peninsula, $\mathrm{AI}=$ Ardley Island, $\mathrm{FP}=$ Fildes Peninsula, $\mathrm{n}$ sites $=$ number of subsamples, $n$ ind. $=$ total number of individuals.

\begin{tabular}{|c|c|c|c|c|c|c|c|}
\hline \multicolumn{2}{|c|}{ Microhabitat Date } & $\begin{array}{l}\text { Area } \\
\left(\mathrm{cm}^{2}\right)\end{array}$ & \multirow[t]{2}{*}{$\begin{array}{c}\mathrm{n} \\
\text { sites }\end{array}$} & Ind. $\mathrm{cm}^{-2}$ & \multicolumn{2}{|c|}{ Sex ratio male \% } & $\begin{array}{c}n \\
\text { ind. }\end{array}$ \\
\hline \multicolumn{7}{|c|}{ Underside of stone } & \\
\hline PP & 20.01.1996 & - & 8 & - & $18.2-50.0$ & 27.8 & 173 \\
\hline PP & 30.01 .1996 & 61.2 & 10 & $0.17 \pm 0.11$ & $0-66.7$ & 18.3 & 82 \\
\hline PP & 12.02.1996 & 61.4 & 10 & $0.26 \pm 0.15$ & $25.5-80.0$ & 42.1 & 176 \\
\hline PP & 22.02 .1996 & 35.8 & 9 & $1.54 \pm 0.74$ & $19.6-59.8$ & 48.2 & 398 \\
\hline PP & 04.03 .1996 & 16.6 & 9 & $2.02 \pm 0.98$ & $13.0-66.7$ & 29.3 & 317 \\
\hline \multicolumn{8}{|c|}{ Open site of rock } \\
\hline \multirow[t]{2}{*}{ AI } & 13.01.2005 & - & 2 & - & & 81.2 & 394 \\
\hline & & & & & & 99.9 & 684 \\
\hline AI & 07.02 .2005 & 111.7 & 3 & $31.25 \pm 3.91$ & $2.8-4.5$ & 4.4 & 375 \\
\hline FP & 07.02 .2005 & 23.7 & 3 & $88.08 \pm 55.0$ & $23.6-48.7$ & 23.6 & 1075 \\
\hline
\end{tabular}

regression: $r^{2}=0.57, \mathrm{~F}_{1,37}=48.94, P=0.001$; Table IV). Aggregations at the lee side of rocks yielded 15- to 500-fold higher mean densities (median 40.1 ind. $\mathrm{cm}^{-2}$ ) (MannWhitney-U $=741, P=0.001$; Table IV). The maximum density was 151 ind. $\mathrm{cm}^{-2}$ (17 February 2005, Lake Kitesh). The estimated size of swarms at these open sites ranged between 698 and 5870 individuals.

In 1996, sex ratios under these stones were clearly female biased in January and March but slightly male biased or equal in February (Potter Peninsula). Sex ratios of open site aggregations were female biased at six sites with a median of 0.18 males per female but two large aggregations in January contained mainly or exclusively males with a sex ratio of 320 males and 74 females and 683 males and 1 female.

In the study of the 1994 season, copulations lasted between 28 seconds and 11 minutes 16 seconds (median 110 seconds, $n=7$ ). Eight and $33 \%$ of the females under stones and $20 \%$ of females on a wind sheltered rock were in copula suggesting high mating frequency. Out of 50 pairs in mating position, 44 were male-female and six were malemale. Six male-female interactions were attacked by approaching males, two of which were separated - a behaviour which also suggests frequent matings.

Egg batches were found to stick to solid material submerged in the shallow water at the shore. They were never found at sites covered by mud or sand. At suitable locations the surface of the substratum was often completely covered with the eggs of several females (e.g. Lake Ripamonti, Ardley Island, 13 January 2005). In the laboratory $61 \%$ of 57 females laid eggs, and the percentage of successful oviposition varied between $44 \%$ and $90 \%$. The first and last clutches occurred 4 and 19 days after capture (median 9 days). The mean ( \pm SD) egg number was $247.2 \pm$ 98.6 eggs per female (range: $49-457, n=34$ ). The number

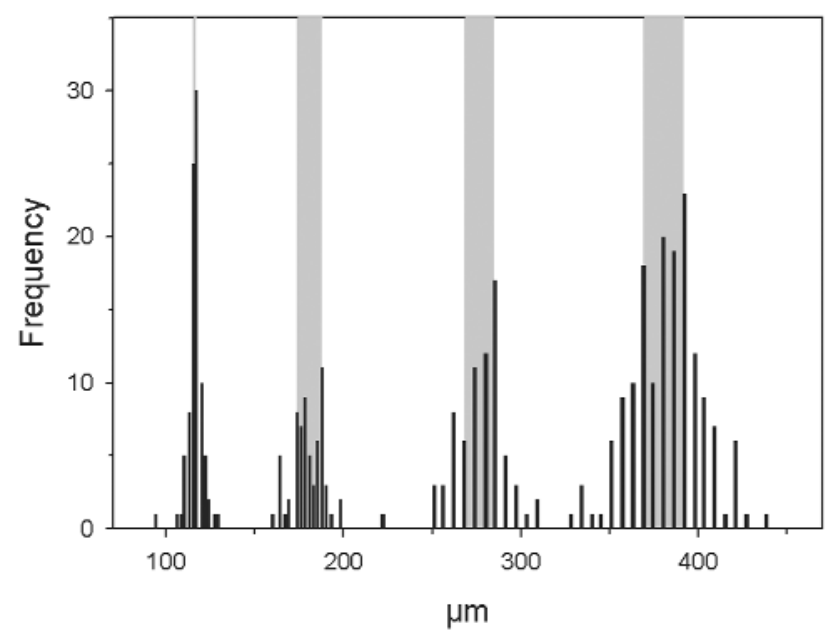

Fig. 2. Frequency distribution of head capsule length $(\mu \mathrm{m})$ of larvae of first to fourth instar of Parochlus steinenii. Grey area gives the 25-75 percentile of each instar group. 
of eggs laid by females in the laboratory did not differ between capture dates $\left(\mathrm{F}_{4,34}=1.96, P=0.13\right)$. Of those females that laid eggs, $62 \%$ produced a single egg batch, $32 \%$ two egg batches and 3\% each three and four, respectively. First egg batches contained $201 \pm 84.8$ eggs, second egg batches $92 \pm 31.6$ eggs and third + fourth batches $49 \pm 17.8$ eggs. Seven field-collected egg batches yielded 60 to 275 eggs (mean $191.7 \pm 79.8$ eggs) which corresponded to laboratory data $\left(\mathrm{t}_{39}=1.39, P=0.17\right)$. Mean egg size was $196.1 \pm 17.9 \mu \mathrm{m}$ and $101.4 \pm 9.8 \mu \mathrm{m}$ in length and width, respectively $(n=21)$.

There were four non-overlapping peaks in the size of the mean head capsule length of larvae (Fig. 2). These are likely to correspond to larval instars. Their means were $116.2 \pm$ $4.38 \mu \mathrm{m}$ (first instar, $n=90$ ), $179.7 \pm 8.47 \mu \mathrm{m}$ (second instar, $n=64), 276.8 \pm 14.47 \mu \mathrm{m}$ (third instar, $n=72$ ) and $382.1 \pm 19.85 \mu \mathrm{m}$ (fourth instar, $n=158$ ). Twenty-five to 35 days after hatching (February/March 1996), laboratory samples contained 59\% first and $41 \%$ second instars $(n=$ 2987). Additional random samples from a freshwater pool in late January and early February 2005 (Fildes Peninsula) contained larvae of second (2\%), third (31\%) and fourth instar $(68 \%, n=235)$.

\section{Discussion}

We found that on King George Island P. steinenii inhabited lakes of any altitude suggesting that altitude is not a barrier for successful reproduction. P. steinenii was found if the water body was permanent, large and contained medium sized stones at the water edge. Stones were found to be important for mating aggregations and oviposition. Mating aggregations occurring under rocks or in terrestrial swarms are likely to represent different mating tactics because they differed grossly in density and sex ratio. Mating and oviposition were frequently observed. Egg hatching occurred rapidly, within a few days of laying, and appeared to be relatively flexible in terms of timing within the season. In addition, $P$. steinenii females laid one to four batches of eggs with a mean number of 192 to 247 eggs/females. This egg output is, on average, 3 - to 8 -fold higher than the other two species occurring in the maritime Antarctic (Peckham 1971, Edwards \& Baust 1981, Convey \& Block 1996) emphasising a high reproductive output.

Below, we discuss which of these ecological, reproductive and developmental traits of $P$. steinenii potentially influence the successful colonization of the types of habitat that already exist or will become available in the course of regional warming. The recent increase of air temperatures in the Maritime Antarctic, especially during winter (King \& Harangozo 1998, Vaughan et al. 2003), combined with increasing precipitation (Turner et al. 1997) will probably alter the duration and thickness of ice cover on freshwater lakes, as well as water depth and the water level variability (Quayle et al. 2003a, 2003b). This may lead, among others to a prolonged activity of adults in the existing habitats and to an increasing number of suitable habitats.

\section{Prolonged activity of adults}

The shorter duration of ice cover and higher water temperatures might facilitate an earlier emergence of the adults because of a rapid development of either eggs or larvae. We found supporting evidence for both possibilities. There was a rapid egg hatching after laying. Furthermore, the simultaneous occurrence in summer of several instars in the field as well as the occurrence of the fourth larval stage in winter (Rauschert 1985) suggests a rapid larval development in P. steinenii. Out of all life-history stages, larvae are most cold resistant and thus the relatively best protected stage in the life cycle of the midge (Shimada et al. 1991). Parochlus steinenii seems to emerge rapidly as soon as the ice cover of the breeding habitat melts. This was observed by Rauschert (1985) who found adults eclosing in midwinter in the sheltered conditions of a pump station at Bellingshausen Station (Fildes Peninsula). Under less protected situations, adults emerged upon the first signs of a melting ice cover (Rauschert 1985). We suggest that the rapid development into the most freeze-protected stage as well as the rapid eclosion in response to ice melting favours a seasonally earlier emergence of $P$. steinenii. Whether this allows a second generation in the Antarctic summer depends on the duration of the developmental programmes in the fourth larval stage.

The distribution of sexes in open ground aggregations was highly variable ranging from female biased ratios to almost exclusively male aggregations (up to 150 ind. $\mathrm{cm}^{-2}$ ). On King George Island, aerial swarming occurs very infrequently (Wirth \& Gressit 1967, cited in Rauschert 1985, personal observation). Therefore, we interpret these ground aggregations as being equivalent to the aerial swarms of chironomids in temperate climates, where males are flying over suitable habitat and attract females for copulation (reviewed in Armitage et al. 1997). However, mating $P$. steinenii were also found under stones (density in these sites ranged from $0.17-2.2$ ind $\mathrm{cm}^{-2}$ - this study, or 0.09-0.174 adults $\mathrm{cm}^{-2}$, Richard et al. 1994). This flexibility in locations suitable for mating encounters may be advantageous under unstable weather conditions. Additionally, $P$. steinenii is likely to mate multiply as suggested by the large number of mating pairs found in a short time interval, the relatively large proportion of females in copula, as well as the high male mating activity. Because we found that $P$. steinenii mates only briefly the large proportion of mating females cannot be the result of extended matings but is more likely to be the result of frequent mating. The presumed high mating frequency of $P$. steinenii increases the likelihood that dispersing adult females have an adequate sperm supply to found a new 
population.

\section{Increasing number of habitats}

The regular occurrence and aggregation at water edges by P. steinenii (e.g. Wirth \& Gressit 1967, Greene et al. 1967, Richard et al. 1994, this study) relates to variability in water levels. The latter, especially if caused by increased temperatures, may expose clutches and larvae to desiccation or flood the mating habitat of adults. The desiccation resistance of $P$. steininii eggs and larvae is unknown, but they can be assumed to depend on a continuous wet environment as in most other chironomids (Armitage et al. 1997), including two other Antarctic species, Eretmoptera murphyi Schaeffer and Belgica antarctica Jacobs (Peckham 1971, Ring et al. 1990). Because the refill of pools by precipitation in summer is unpredictable we conclude that variable water levels should inhibit the successful reproduction by $P$. steinenii.

However, we found indirect evidence that $P$. steinenii may circumvent this problem through habitat selection. Despite their frequent availability, temporal melt water ponds or lakes with variable water levels and shallow shores were not occupied by midges. Because adults were also primarily found at permanent lakes they may have evolved some kind of habitat preference. Which cues of permanent lakes are used by adult midges in their decision to lay eggs is unknown and open to experimental manipulation. In any case, there is a double advantage of choosing deeper lakes with stable water levels. Firstly, shallow freshwater bodies will respond much more strongly to higher temperatures in that a larger area of water surface shrinks. Secondly, Parochlus larvae can only tolerate low temperatures to $-3^{\circ} \mathrm{C}$ (lower lethal temperature, Shimada et al. 1991). Presently, variable lakes and temporary ponds do not reach a sufficient depth to guarantee survival of larvae: in the maritime Antarctic ice cover on lakes reach $>1 \mathrm{~m}$ thickness during winter (Butler et al. 2000) Hence, we can expect that higher winter air temperatures might lead to a decrease in ice thickness and parallel an increasing number of suitable habitats.

\section{Acknowledgements}

We thank P. Convey and H.-U. Peter for comments on the manuscript and $\mathrm{H}$. Chung for great hospitality at Korean King Sejong Station in 2005. We also thank Dr R. Worland and an unnamed referee for their useful criticisms. Several of the results presented were obtained during expeditions which were financially supported by the German Research Council (PE 454), the State of Thuringia/Germany (Landesgraduiertenstipendium) and the German Federal Environmental Agency (FKZ 20313 124).

\section{References}

Armitage, P.D., Cranston, P.S. \& Pinder, L.C.V. 1997. The chironomidae, the biology and ecology of non-biting midges. London: Chapman \& Hall, 572 pp.

Barsch, D., Blümel, W.-D., Flügel, W.-A., Mäusbacher, R., Stäblein, G. \& ZICK, W. 1985. Untersuchungen zum Periglazial auf der KönigGeorg-Insel Südshetlandinseln/Antarktika. Reports on Polar Research, 24, 1-75.

BRUNDIN, L. 1966. Transantarctic relationships and their significance, as evidenced by chironomid midges, with a monograph of the subfamilies Podominae and Aphroteniinae and the austral Heptagyiae. Kungliga Svenska Vetenskapsakademiens Handlingar, 11, 1-472.

Butler, H.G., Edworthy, M.G. \& Ellis-Evans, J.C. 2000. Temporal plankton dynamics in an oligotrophic maritime Antarctic lake. Freshwater Biology, 43, 215-230.

Convey, P. 2001. Terrestrial ecosystem responses to climate changes in the Antarctic. In Walther, G.R., Burga, C.A. \& Edwards, P.J., eds. "Fingerprints" of climate change: adapted behaviour and shifting species ranges. New York: Kluwer Academic/Plenum Publishers, $17-42$.

Convey, P. 2003. Maritime Antarctic climate change: signals from terrestrial biology. Antarctic Research Series, 79, 145-158.

Convey, P. \& Block, W. 1996. Antarctic diptera: ecology, physiology and distribution. European Journal of Entomology, 93, 1-13.

EDWARDS, J.S. \& BAUST, J. 1981. Sex-ratio and adult behaviour of the Antarctic midge Belgica antarctica (Diptera, Chironomidae). Ecological Entomology, 6, 239-243.

Edwards, M. \& Usher, M.B. 1985. The winged Antarctic midge Parochlus steinenii (Gerke) (Diptera: Chironomidae) in the South Shetland Islands. Biological Journal of the Linnean Society, 26, 83-93.

Fowbert, J.A. \& SMITH, R.I.L. 1994. Rapid increase in native vascular plants in the Argentine Islands, Antarctic Peninsula. Arctic and Alpine Research, 26, 290-296.

Frenot, Y., Chown, S.L., Whinam, J., Selkirk, P.M., Convey, P., Skotnicki, M. \& Bergstrom, D.M. 2005. Biological invasions in the Antarctic: extent, impacts and implications. Biological Reviews, 80, 45-72.

Gerighausen, U., Bräutigam, K., Mustafa, O. \& Peter, H.-U. 2003. Expansion of vascular plants on an Antarctic island - a consequence of climate change? In Huiskes, A.H.L., Gieskes, W.W.C., Rozema, J., Schorno, R.M.L., VAN DER Vies, S.M. \& WolfF, W.J., eds. Antarctic biology in a global context. Leiden: Bachhuys Publishers, 79-83.

GERKE, G. 1889. Vorläufige Nachricht über die Fliegen Süd-Georgiens, nach der Ausbeute der Deutschen Station 1882-1883. Jahrbuch der Hamburger Wissenschaftichen Anstalt, 6, 153-154.

Greene, S.W., Gressit, J.L., Korb, D., Llano, G.A., Rudolph, E.D., Singer, R., Steere, W.C. \& Ugolini, F.C.1967. Terrestrial life in Antarctica. Antarctic Map Folio Series, 5, 11 plates.

King, J.C. \& Harangozo, S.A. 1998. Climate change in the western Antarctic Peninsula since 1945: observations and possible causes. Annals of Glaciology, 27, 571-575.

Peckham, V. 1971. Notes on the chironomid midge Belgica antarctica Jacobs at Anvers Island in the maritime Antarctic. Pacific Insects Monographs, 25, 145-166.

Quayle, W.C., Convey, P., Peck, L.S., Ellis-Evans, J.C., Butler, H.G. \& PEAT, H.J. 2003a. Ecological responses of maritime Antarctic lakes to regional climate change. Antarctic Research Series, 79, 159-170.

Quayle, W.C., Peck, L.S., Peat, H.J., Ellis-Evans, J.C. \& Harrigan, P.R. 2003b. Extreme responses to climate change in Antarctic lakes. Science, 295, 645 .

Rauschert, M. 1985. Beobachtungen an der Chironomidae Parochlus steineni auf der Insel King George (Südshetlandinseln, Antarktis) (Diptera, Chironomidae). Deutsche Entomologische Zeitschrift, Neue Folge, 32, 183-188. 
Richard, K.J., Convey, P. \& Block, W. 1994. The terrestrial arthropod fauna of the Byers Peninsula, Livingston Island, South Shetland Islands. Polar Biology, 14, 371-379.

Ring, R.A., Block, W., Somme, L. \& Worland, M.R. 1990. Body water content and desiccation resistance in some arthropods from subantarctic South Georgia. Polar Biology, 10, 581-588.

SCHMID, P.E. 1993. A key to the larval Chironomidae and their instars from Austrian Danube region streams and rivers; with particular reference to a numerical taxonomic approach. Wasser und Abwasser Suppl., 1-512.

Shimada, K., Ohyama, Y. \& Pan, C.X. 1991. Cold-hardiness of the Antarctic winged midge Parochlus steinenii during the active season at King George Island. Polar Biology, 11, 311-314.

SмITH, R.I.L. 1996. Introduced plants in Antarctica: potential impacts and conservation issues. Biological Conservation, 76, 135-146.

Tokeshi, M. 1997. Production ecology. In Armitage, P.D., Cranston, P.S. \& PINDER, L.C.V., eds. The chironomidae, the biology and ecology of non-biting midges. London: Chapman \& Hall, 269-296.
Torres, B.A. 1956. Primer hallazgo de Tendipedidos alados en la Region Antarctica. Podonominae, una nueva subfamilia para la citada region. Anales de la Sociedad Cientifica Argentina, 161, 41-52.

Turner, J., Colwell, S.R. \& Harangozo, S. 1997. Variability of precipitation over the coastal western Antarctic Peninsula from synoptic observations. Journal of Geophysical Research Atmospheres, 102, 13 999-14 007.

Vaughan, D.G., Marshall, G.J., Connolley, W.M., Parkinson, C., Mulvaney, R., Hodgson, D.A., King, J.C., Pudsey, C.J. \& Turner, J. 2003. Recent rapid regional climate warming on the Antarctic Peninsula. Climatic Change, 60, 243-274.

Vogel, M. \& Nicolai, V. 1983. Invertebrates collected at the old whaling station, Grytviken, South Georgia. Polar Record, 135, 607-609

WirTh, W.W. \& Gressit, J.L. 1967. Diptera: Chironomidae (midges). Antarctic Research Series, 10, 197-203. 
